\title{
ISOLASI DAN IDENTIFIKASI SENYAWA AAPTAMINOID DARI Aaptos aaptos DAN POTENSI PEMANFAATANNYA UNTUK PENCEGAHAN INFEKSI BAKTERI Vibrio harveyi
}

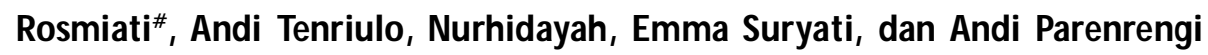 \\ * Balai Riset Perikanan Budidaya Air Payau dan Penyuluhan Perikanan \\ Jl. Makmur Dg. Sitakka No. 129, Maros 90512, Sulawesi Selatan
}

(Naskah diterima: 16 September 2019; Revisi final: 19 November 2019; Disetujui publikasi: 22 November 2019)

\begin{abstract}
ABSTRAK
Sponge Aaptos aaptos diketahui mengandung senyawa turunan aaptaminoid yang dapat digunakan sebagai sumber antibakterial alami tanpa efek samping. Penelitian ini bertujuan untuk mendapatkan senyawa bioaktif dari ekstrak butanol Aaptos aaptos yang efektif menghambat pertumbuhan Vibrio harveyi dan mengeval uasi kemampuan senyawa bioaktif dalam pencegahan infeksi V. harveyi. Ekstraksi metabolit sekunder menggunakan metode maserasi, sementara isolasi dan identifikasi senyawa aaptaminoid dengan metode kolom kromatografi dan spektroskopi. Uji aktivitas antibakterial menggunakan metode difusi agar dengan paper disc. Evaluasi kemampuan senyawa aktif dalam pencegahan vibriosis menggunakan metode eksperimental dengan empat perlakuan dengan masing-masing perlakuan menggunakan hewan uji Litopenaeus vannamei sebanyak 10 ekor/akuarium. Dosis senyawa aktif yang digunakan yaitu; A) $0 \mu \mathrm{g} / \mathrm{g}$ berat badan (bb); B) $0,67 \mu \mathrm{g} / \mathrm{g}$ bb; C) $25 \mu \mathrm{g} / \mathrm{g}$ bb; dan D) $50 \mu \mathrm{g} / \mathrm{g}$ bb. Penyuntikan $100 \mu \mathrm{L}$ senyawa aktif pada masing-masing dosis tersebut dilakukan pada awal penelitian dan setelah 14 hari pemeliharaan, udang diuji tantang dengan V. harveyi pada kepadatan $10^{7} \mathrm{CFU} / \mathrm{mL}$ Pemeliharaan udang dilanjutkan selama tujuh hari. Hasil penelitian menunjukkan bahwa perubahan morfologi udang berupa telson, rostrum, tubuh, pereopoda, dan pleopoda memerah sebagai tanda-tanda udang terinfeksi mulai diamati pada 23 jam pasca penginfeksian. Udang pada perlakuan C dan D mulai pulih dari infeksi pada hari keempat yang ditandai oleh telson, rostrum, tubuh, pereopoda, dan pleopoda yang normal. Selain itu, perlakuan D juga menunjukkan nilai sintasan udang tertinggi $(50 \%)$, sementara perlakuan $\mathrm{C}$ memberikan sintasan sebesar $25 \%$ Sebaliknya pada perlakuan B dan A (kontrol) udang sudah mengalami kematian 100\%sebelum 24 jam pasca penginfeksian. Dari hasil penelitian ini dapat disimpulkan bahwa senyawa aaptaminoid pada dosis e" $25 \mu \mathrm{g} / \mathrm{g}$ bb dapat dikembangkan sebagai sumber alternatif untuk pencegahan vibriosis.
\end{abstract}

KATA KUNCl: aaptaminoid; Litopenaeus vannamei; vibriosis

ABSTRACT: Isolation and identification of aaptaminoid from Aaptos aaptos and its potential use for vibriosis prevention. By: Rosmiati, Andi Tenriulo, Nurhidayah, Emma Suryati, and Andi Parenrengi

\begin{abstract}
Aaptos aaptos contains aaptaminoid widely known as a natural antibacterial without any side effect. This recent research aimed to extract bioactive compounds from butanol extract of Aaptos aaptos and determined its efficacy to inhibit the growth and prevent the infection of Vibrio harveyi. The extraction of secondary metabolites used maceration method, while isolation and identification of aaptaminoid used column chromatography and spectroscopy methods. The antibacterial test against $\mathbf{V}$. harveyi used agar diffusion method using paper disc. The evaluation of the active compound during the vibrio challenge test used an experimental method with four treatments. Each treatment used whiteleg shrimp, Litopenaeus vannamei of $10 \mathrm{ind}$./aquarium. Dosages of the active compound used were A) $0 \mu \mathrm{g} / \mathrm{g} b \mathrm{~b}$, B) $0.67 \mu \mathrm{g} / \mathrm{g} \mathrm{bb}, C) 25 \mu \mathrm{g} / \mathrm{g} b \mathrm{~b}$, and D) $50 \mu \mathrm{g} / \mathrm{g} b \mathrm{~b}$. The injection of $100 \mu \mathrm{L}$ of each bioactive compound was carried out at the initial experiment and on day 14 after challenged with V. harveyi at the density of $10^{7} \mathrm{CFU} / \mathrm{mL}$. The shrimps was reared for an additional seven days. The findings showed that the infection on shrimps started on 23 hours postinjection of $\mathbf{V}$. harveyi indicated by the reddish color of rostrum, body, pereopods, pleopods, and telson. The shrimps in treatment $C$ and $D$ were able to recover from the infection started on the day- 4 post-infection exhibited by the back to
\end{abstract}

\footnotetext{
\# Korespondensi: Balai Riset Perikanan Budidaya Air Payau dan Penyuluhan Perikanan. JI. Makmur Dg. Sitakka No. 129,

Maros 90512, Sulawesi Selatan, Indonesia

Tel. + 62411371545

E-mail: emirosmiati@ yahoo.com
} 
the normal condition of rostrum, body, pereopods, pleopods, and telson. The highest survival rate post-infection was obtained by shrimp in treatment D $(50 \%$ followed by treatment C $(25 \%$. In turn, shrimps on treatment A and B had $100 \%$ mortality within 24 hours post-infection. This research concludes that aaptaminoid can be developed as an antibacterial agent for vibriosis prevention with an optimal dosage of e" $25 \mu \mathrm{g} / \mathrm{g} b \mathrm{~b}$.

\section{KEYWORDS: aaptaminoid; Litopenaeus vannamei; vibriosis}

\section{PENDAHULUAN}

Menurut Kementerian Kelautan dan Perikanan (KKP), penyakit vibriosis yang disebabkan oleh bakteri dari jenis Vibrio sp. adalah salah satu jenis penyakit udang yang bisa meningkatkan kematian pada udang saat masih berada di dalam tambak hingga 100\% (Ambari, 2018).

Upaya pencegahan penyakit vibriosis tersebut telah dilakukan melalui penggunaan tandon, biofilter, biokontrol, biosekuriti, imunostimulan, dan skrining benur, namun upaya tersebut belum maksimal sehingga dibutuhkan alternatif lain. Pencarian formula untuk menghadang penyakit vibriosis terus digal akkan salah satunya dengan penggunaan bahan alam. Organisme yang bersumber dari lingkungan laut kaya akan senyawa kimia dan aktivitas biologi. Senyawa yang diisolasi dari organisme laut memiliki aktivitas spektrum yang luas melawan berbagai macam penyakit tanpa efek samping yang berbahaya (Mayer \& Hamman, 2002).

Pencarian senyawa bioaktif yang bersumber dari lingkungan laut di mulai dengan melakukan skrining antibakterial aktiviti dari enam spesies sponge (Aaptos aaptos, Aaptos suberitoides, Callyspongia sp., Callyspongia pseudoreticulata, Haliclona sp., and Clathria reinwardti) terhadap Vibrio sp. dan Vibrio harveyi. Dari skrining antibakterial tersebut diperoleh bahwa ekstrak metanol Aptos aaptos dapat menghambat pertumbuhan Vibrio sp. dan V. harveyi secara kuat dengan diameter zona hambatan $45 \pm 0,5 \mathrm{~mm}$ (Vibrio sp.) dan $34 \pm 0,1$ $\mathrm{mm}$ (Vibrio harveyi) (Rosmiati et al., 2011). Partisi berdasarkan kepolaran senyawa menggunakan pelarut dietil eter, butanol, dan air dilakukan terhadap ekstrak metanol Aaptos aaptos dilanjutkan dengan uji hayati diperoleh bahwa ekstrak butanol mampu menghambat pertumbuhan Vibrio harveyi dengan zona hambatan 23 $\pm 0,1 \mathrm{~mm}$ (Rosmiati \& Muliani, 2019). Berdasarkan hasil tersebut, perlu dilakukan kajian lebih lanjut terhadap kandungan senyawa bioaktif ekstrak butanol Aaptos aaptos, serta potensinya dalam penanggulangan penyakit vibriosis. Oleh karena itu, tujuan penelitian ini adalah; (1) mendapatkan senyawa bioaktif yang efektif menghambat pertumbuhan V. harveyi dan (2) menentukan aktivitas antibakterial senyawa aaptaminoid terhadap V. harveyi.

\section{BAHAN DAN METODE}

\section{Ekstraksi, Isolasi, dan Pemurnian Senyawa Aaptaminoid}

Sponge Aaptos aaptos dikumpulkan dari Pulau Barrang Lompo, Sulawesi Selatan. Sponge ditempatkan dalam plastik klip dan dimasukkan dalam sebuah cool box yang telah diisi es batu dan dibawa ke laboratorium Bioteknologi Balai Riset Perikanan Budidaya Air Payau dan Penyuluhan Perikanan (BRPBAP3), Maros.

Ekstraksi dan isolasi senyawa aaptaminoid mengacu pada metode Mohamad et al., 2017. Sekitar 0,5 kg sampel halus kering dimaserasi menggunakan metanol pada suhu ruangan. Partisi ekstrak metanol berdasarkan kepolaran menggunakan pelarut dietil eter, butanol, dan air untuk mendapatkan ekstrak butanol kering setelah dievaporasi $(7,0 \mathrm{~g})$. Ekstrak butanol kering difraksionasi dengan kolom kromatografi vakum kering untuk mendapatkan 17 fraksi. Melalui fraksionasi yang diikuti dengan uji bioassay diperoleh bahwa fraksi 11 dan 12 mampu menghambat pertumbuhan V. harveyi. Fraksi 11 dan 12 digabung (berdasarkan hasil kromatografi lapis tipis) dan di kolom kromatografi silika geL secara berulang untuk mendapatkan campuran senyawa aaptaminoid. Campuran senyawa tersebut dimurnikan dengan kolom kromatografi $\mathrm{LH}-20$ yang dielusi dengan $\mathrm{CHCl}_{3} / \mathrm{MeOH}$, 1:1 sehingga diperoleh senyawa-1 $(75 \mathrm{mg}), 2(50 \mathrm{mg})$, 3 (2 mg), 4 (6 mg), dan 5 (2,7 mg).

\section{Uji Aktivitas Antibakterial In Vitro}

Uji aktivitas antibakterial menggunakan Vibrio harveyi (bakteri patogen koleksi BRPBAP3 tahun 2019). Uji aktivitas ekstrak, fraksi, dan senyawa murni terhadap Vibrio harveyi menggunakan metode difusi agar dengan paper disc (Rosmiati et al., 2011). Seratus $\mu \mathrm{L}$ bakteri Vibrio harveyi dipipet dan diteteskan pada media mueller, diratakan dengan stick. Paper discs (6 $\mathrm{mm}$ ) diletakkan pada permukaan media lalu diteteskan dengan ekstrak butanol, fraksi ekstrak butanol dan senyawa murni dengan $20 \mu \mathrm{L}$ dari konsentrasi $10 \mathrm{mg} /$ $\mathrm{mL}(100 \mu \mathrm{g} / \mathrm{disc})$ untuk ekstrak dan fraksi dan $1 \mathrm{mg} /$ $\mathrm{mL}(10 \mu \mathrm{g} / \mathrm{disc})$ untuk senyawa murni. Paper discs dikeringkan dalam laminar air flow dan selanjutnya ditempatkan di atas agar yang sebelumnya telah 
diinokulasi dengan bakteri. Cawan petri diinkubasi pada suhu $28^{\circ} \mathrm{C}$ selama 24 jam dan diameter zona hambatan yang diindikasikan oleh zona bening di sekitar paper disc diukur dalam mm. Streptomicin dengan konsentrasi $30 \mu \mathrm{g} /$ disc digunakan sebagai kontrol positif.

\section{Identifikasi dan Elusidasi Struktur Senyawa Aaptaminoid}

Senyawa bioaktif yang berhasil diisolasi dan dimurnikan diidentifikasi golongan senyawanya menggunakan metode kromatografi lapis tipis (KLT) pada sebuah pelat dengan Si.gel $F_{254}$ (ketebalan 0,2 $\mathrm{mm}$; M erck, Darmstadt, Germany) sebagai fase diam. Pelat KLT yang telah ditetesi senyawa bioaktif dielusi dengan campuran pelarut $\left(\mathrm{CH}_{2} \mathrm{Cl}_{2}: \mathrm{MeOH} ; 9: 1,5: 1, \mathrm{v} /\right.$ v), $\left(\mathrm{CH}_{2} \mathrm{Cl}_{2}\right.$ : Acetone; $\left.1: 1 \mathrm{v} / \mathrm{v}\right)$ dan $\left(\mathrm{CHCl}_{3}: \mathrm{MeOH} ; 9: 1\right.$, $8: 2,7: 3, \mathrm{v} / \mathrm{v})$. Deteksi golongan senyawa dilakukan menggunakan lampu UV pada panjang gelo mbang 344 $\mathrm{nm}$ dengan bantuan semprotan larutan pendeteksi Dragendorff. Elusidasi struktur senyawa bioaktif dengan metode spektrometri yaitu gas cromatography mass spectrometry (GCMS) dan electron ion mass spektometry (EIMS) untuk penentuan berat molekul dan formula senyawa, ${ }^{1} \mathrm{H}$ - dan ${ }^{13} \mathrm{C}$-nuclear magnetic resonance spectroscopy (NMR) data digunakan untuk menentukan jumlah proton $(\mathrm{H})$ dan karbon $\left(\mathrm{C}_{13}\right)$. Data correlation spectroscopy (COSY) digunakan untuk menentukan pasangan proton-proton, data heteronuclear multiple quantum coherence (HM QC) untuk penentuan ikatan proton-carbon, sementara data heteronuclear multiple bond correlation (HMBC) untuk penentuan hubungan (konektivitas) proton-karbon jarak jauh dan untuk menandai resonansi karbon quartenari. Semua data spektrometer dibandingkan dengan data publikasi.

\section{Evaluasi Potensi Senyawa Aaptaminoid Sebagai Antibakterial Terhadap Vibrio harveyi pada Udang (L. vannamei)}

Udang yang digunakan untuk uji tantang adalah udang vaname (Litopenaeus vannamei) yang dikumpulkan dari tambak Kabupaten Barru, Sulawesis Selatan. Sebelum dilakukan uji tantang terlebih dahulu dilakukan penentuan konsentrasi hambat minimum (KHM) in vitro sebagai dasar untuk penentuan konsentrasi senyawa-2 (9-demetilaaptamin) yang digunakan. Penentuan KHM dilakukan dengan membuat series larutan senyawa-2 pada konsentrasi $1.000,500,250,100,10,1$, dan 0 mg/L. Penentuan KHM menggunakan metode difusi agar dengan paper disc seperti digambarkan pada metode uji aktivitas antibakterial (Rosmiati et al., 2011).
Dari pengujian konsentrasi yang dilakukan diperoleh bahwa KHM senyawa-2 (9-demetilaaptamin) adalah $100 \mathrm{mg} / \mathrm{L}$ sehingga dosis 100, 250, dan 500 $\mathrm{mg} / \mathrm{L}$ dipilih untuk digunakan sebelum dilakukan uji tantang dengan V. harveyi. Sebelum dilakukan uji tantang, udang vaname dengan bobot $\pm 15 \mathrm{~g}$ sebanyak 40 ekor dipelihara dalam empat akuarium dengan mengacu pada Sukenda (2007) yaitu sebanyak 10 ekor/ akuarium. Hewan uji diaklimatisasi selama 14 hari sebelum diberikan perlakuan. Metode penelitian menggunakan rancangan acak lengkap yang terdiri atas empat perlakuan dengan ulangan individu. Hewan uji diinjeksi dengan $100 \mu \mathrm{L}$ senyawa-2 pada segmen kedua pada konsentrasi, A) $0 \mu \mathrm{g} / \mathrm{g}$ bb; B) $(0,67 \mu \mathrm{g} / \mathrm{g}$ bb); C) 25 $\mu \mathrm{g} / \mathrm{g}$ bb; dan D) $50 \mu \mathrm{g} / \mathrm{g}$ bb (konsentrasi berdasrkan KHM yaitu $100 \mathrm{mg} / \mathrm{L}(0,67 \mu \mathrm{g} / \mathrm{g}$ bb), $250 \mathrm{mg} / \mathrm{L}(25 \mu \mathrm{g} / \mathrm{g}$ bb), dan $500 \mathrm{mg} / \mathrm{L}(50 \mu \mathrm{g} / \mathrm{g}$ bb). Prosedur yang dilakukan dalam uji ini adalah setelah udang diinjeksi senyawa bioaktif selama 14 hari, udang diinfeksi dengan bakteri V. harveyi dengan disuntik dengan kepadatan $10^{7} \mathrm{CFU} / \mathrm{mL}$ sebanyak $100 \mu \mathrm{L}$. Pemeliharaan dilanjutkan sampai tujuh hari pasca penginfeksian. Selama pemeliharaan udang diberi pakan komersial sebayak 4,5\%bobot badan dengan pemberian tiga kali/ hari yaitu pada pukul 06:00, 12:00, dan 18:00. Parameter yang diamati meliputi respons pakan, gejala klinis, dan tingkat sintasan.

\section{HASIL DAN BAHASAN}

\section{Identifikasi dan Elusidasi Struktur Aaptaminoid}

Semua senyawa yang berhasil diisolasi dari ekstrak butanol Aaptos aaptos berasal dari golongan senyawa alkaloid yang diindikasikan oleh kehadiran spot berwarna orange setelah disemprot dengan larutan Dragendorf. Senyawa-1 telah diisolasi sebagai tepung yang berwarna kuning kehijau-hijauan (75 mg). Hasil kromatografi lapis tipis (KLT) menunjukkan nilai retention of flow $\left(R_{f}\right)=0,16$ (diklorometan $(D C M) /$ metanol $(\mathrm{MeOH} ; 8: 2)$ ). Data spektrum GCMS menunjukkan $\mathrm{m} /$ z 228 yang sesuai dengan formula molekul $\mathrm{C}_{13} \mathrm{H}_{12} \mathrm{~N}_{2} \mathrm{O}_{2}$. Data fisik dan NMR, serta perbandingan dengan data literatur yang dipublikasikan oleh Calcul et al. (2003), senyawa-1 diidentifikasi sebagai aaptamin.

Senyawa-2 telah diisolasi sebagai padatan berwarna kuning (11 mg). Hasil KLT menunjukkan nilai $R_{f}=0,2$ (Asetonitril/MeOH; 2:8). Data electron ion mass spectrum (EIMS) menunjukkan $\mathrm{m} / \mathrm{z} 214$ yang menyarankan formula molekul $\mathrm{C}_{12} \mathrm{H}_{10} \mathrm{~N}_{2} \mathrm{O}_{2}$. Data fisik dan NMR, serta perbandingan dengan data literatur (Pedpradab, 2005), senyawa-2 identik dengan 9-demetilaaptamine. 
Senyawa-3 telah diisolasi sebagai minyak berwarna kuning pucat $(6 \mathrm{mg})$. Hasil KLT menunjukkan nilai $\mathrm{R}_{\mathrm{f}}=$ 0,2 (DCM/MeOH; 8:2). Data EIMS menunjukkan $\mathrm{m} / \mathrm{z}$ 242 yang sesuai dengan formula molekul $\mathrm{C}_{14} \mathrm{H}_{14} \mathrm{~N}_{2} \mathrm{O}_{2}$. Data fisik dan NMR, serta perbandingan dengan data literatur (Herlt et al., 2004), senyawa-3 sesuai dengan 4-N-metilaaptamin.

Senyawa-4 telah diisolasi seperti getah berwarna coklat $(2,7 \mathrm{mg})$. Hasil KLT menunjukkan nilai $R_{f}=0,26$ (DCM/MeOH; 8:2). Data EIMS menunjukkan m/z 258 yang sesuai dengan formula molekul $\mathrm{C}_{14} \mathrm{H}_{14} \mathrm{~N}_{2} \mathrm{O}_{3}$. Data fisik dan NMR, serta perbandingan dengan data literatur (Calcul et al., 2003), senyawa-4 diidentifikasi sebagai 9-metoksiaaptamin.

Senyawa-5 telah diisolasi sebagai kristal berwarna kuning (2,0 mg). Hasil KLT menunjukkan nilai $R_{f}=0,5$ (Klorofom/Aseton; 1:1). Data EIMS menunjukkan $\mathrm{m} / \mathrm{z}$ 212 yang menyarankan formula molekul $\mathrm{C}_{12} \mathrm{H}_{8} \mathrm{~N}_{2} \mathrm{O}_{2}$. Data fisik dan NMR, serta perbandingan dengan data literatur (Calcul et al., 2003), senyawa-5 diidentifikasi sebagai 9-demetiloksiaaptamin. Struktur kimia dan data NM R dari senyawa 1-5 disimpulkan dalam Gambar 1 dan Tabel 1, 2, dan 3.

\section{Aktivitas Antibakterial Senyawa 1-5 Terhadap V. harveyi In Vitro}

Hasil uji aktivitas antibakterial menunjukkan bahwa senyawa-1-5 mampu menghambat pertumbuhan
V. harveyi dengan diameter zona hambatan yang berbeda-beda seperti ditunjukkan dalam Tabel 4.

Dari Tabel 4 terlihat bahwa senyawa-2, 3, dan 4 menunjukkan diameter zona hambatan e" 20 mm yang mengindikasikan bahwa senyawa tersebut mempunyai daya hambat yang sangat kuat terhadap V. harveyi berdasarkan uji antibiotikmikrobiologi dengan discplate method yang dilaporkan oleh Davis \& Stout (1971) bahwa senyawa murni dengan diameter zona hambat 20-30 mm tergolong dalam kategori zona hambat sangat kuat, diameter zona hambat $10-20 \mathrm{~mm}$ tergolong dalam kategori zona hambat kuat. Bila dibandingkan dengan diameter zona hambatan yang ditunjukkan oleh streptomicin, diameter zona hambatan yang ditunjukkan oleh senyawa-2 dan senyawa-4 lebih kecil. Ini karena adanya perbedaan konsentrasi antibiotik streptomicin yang digunakan yaitu lebih besar $35 \mu \mathrm{g} /$ disc. Mekanisme kerja senyawa1-5 yang merupakan turunan senyawa alkaoid sebagai antibakteri yaitu dengan mengganggu peptidoglikan yang mengakibatkan terjadinya lisis pada lapisan dinding sel bakteri (Septiana \& Simanjuntak, 2015). Berbeda dengan bakteri Gram positif, V. harveyi yang merupakan bakteri Gram negatif memiliki lapisan peptidoglikan yang tipis menyebabkan dinding selnya lebih rentan mengalami kerusakan ketika diberikan antibakteri (Radji, 2011).

Kemampuan suatu senyawa dalam menghambat pertumbuhan mikroba tergantung konsentrasi dari

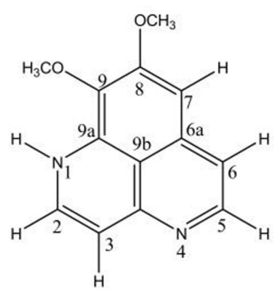

1<smiles>COC1=C(OC)c2cccc3cccc(c23)C=C1</smiles>

2<smiles></smiles>

3<smiles>COc1cc2ccc3nccc4[nH]c(c1)c2c34</smiles>

4<smiles>COC1(OC)C=CC2=CC=NC3=CC=NC23C=C1</smiles>

5

Gambar 1. Struktur senyawa aaptamin (1), 9-demetilaaptamin (2), 4-N-metilaaptamin (3), 9-demetiloksiaaptamin (4), dan 9-metoksiaaptamin (5).

Figure 1. Chemical structure aaptamine (1), 9-demetylaaptamine (2), 4-N-metylaaptamine (3), 9-demetyloxyaaptamine (4), and 9-metoxyaaptamine (5). 
Tabel 1. Data spektrum NMR aaptamin (1) dan 9-demetilaaptamin (2)

Table 1. NM R spectrum data of aaptamine(1) and 9-demetylaaptamine(2)

\begin{tabular}{|c|c|c|c|c|c|c|}
\hline \multirow{2}{*}{$\begin{array}{c}\text { Posisi (Position) } \\
\text { C/H }\end{array}$} & \multicolumn{3}{|l|}{-1} & \multicolumn{3}{|c|}{-2} \\
\hline & $\begin{array}{c}\delta^{1} H(m, J \text { in } 400 \mathrm{MHz}) \\
\text { in } \mathrm{CD}_{3} \mathrm{OD}\end{array}$ & $\delta^{13} \mathrm{C}$ & HMBC & $\begin{array}{c}\delta^{1} H(m, J \text { in } 400 \mathrm{MHz}) \\
\text { in } \mathrm{CD}_{3} \mathrm{OD}\end{array}$ & $\delta^{13} \mathrm{C}$ & HMBC \\
\hline \multicolumn{7}{|l|}{$1 \mathrm{NH}$} \\
\hline 2 & $7.78(d, 7.2)$ & 141.1 & $3,9 a, 3 a$ & $7.71(d, 6.8)$ & 141.3 & 2,3,9a,3a \\
\hline 3 & $6.35(d, 7.2)$ & 97.7 & $9 b, 2$ & $6.23(d, 6.8)$ & 96.8 & $3,2,9 b$ \\
\hline $3 a$ & - & 150.4 & & & 150.6 & \\
\hline 5 & $7.27(d, 7.6)$ & 129.1 & $6,6 a, 3 a$ & $7.11(d, 7.2)$ & 126.9 & $5,6,3 a, 6 a$ \\
\hline 6 & $6.88(d, 7.6)$ & 113.0 & $7,9 b, 5$ & $6.82(d, 7.2)$ & 113.3 & $6,5,7,9 b$ \\
\hline $6 a$ & - & 132.9 & & & 130.4 & \\
\hline 7 & 7.07 (s) & 100.8 & $6,9 b, 9,8$ & $7.06(s)$ & 100.3 & $7,8,6 a, 6,9 b, 9$ \\
\hline 8 & - & 157.5 & & & 128.7 & \\
\hline 9 & - & 132.0 & & & 152.3 & \\
\hline $9 a$ & - & 133.9 & & & 128.5 & \\
\hline $9 b$ & - & 116.7 & & & 117.0 & \\
\hline $8-\mathrm{OCH}_{3}$ & 4.06 (s) & 55.6 & 8 & 4.06 (s) & 55.7 & 9 \\
\hline 9-OH & 3.95 (s) & 59.7 & 9 & & & \\
\hline
\end{tabular}

Keterangan (Note): $\mathrm{C}$ (karbon/carbon), $\mathrm{H}$ (proton), $\mathrm{N}$ (nitrogen), $\mathrm{OCH}_{3}$ (metoksi/metoxy), $\mathrm{OH}$ (hidroksi/hydroxy)

Tabel 2. Data spektrum NMR 4-N-metilaaptamin (3) dan 9-demetiloksiaaptamin (4)

Table 2. NM R spectrum data of 4-N-metylaaptamine (3) and 9-demetyloxyaaptamine (4)

\begin{tabular}{|c|c|c|c|c|c|c|}
\hline \multirow{2}{*}{$\begin{array}{c}\text { Posisi (Position) } \\
\text { C/H }\end{array}$} & \multicolumn{3}{|l|}{3} & \multirow[b]{2}{*}{$\begin{array}{c}\delta^{1} \mathrm{H}\left(\mathrm{m}_{1} \mathrm{~J} \text { in } 400 \mathrm{MHz}\right) \\
\text { in } \mathrm{CD}_{3} \mathrm{OD}\end{array}$} & \multirow[b]{2}{*}{$\delta^{13} \mathrm{C}$} & \multirow[b]{2}{*}{ HMBC } \\
\hline & $\begin{array}{c}\delta^{1} H\left(m_{1} J \text { in } 400 \mathrm{MHz}\right) \\
\text { in } \mathrm{CD}_{3} \mathrm{OD}\end{array}$ & $\delta^{13} \mathrm{C}$ & HMBC & & & \\
\hline \multicolumn{7}{|l|}{$1 \mathrm{NH}$} \\
\hline 2 & $7.79(d, 7.2)$ & 141.1 & $3,9 a, 3 a$ & $9.09(d, 5.4)$ & 150.4 & $3,9 a, 3 a, 2$ \\
\hline 3 & $6.36(d, 7.2)$ & 97.7 & $9 b, 2$ & $8.26(d, 5.4)$ & 128.4 & $9 b, 3,2$ \\
\hline $3 a$ & & 150.3 & & & 150.6 & \\
\hline 5 & $7.26(d, 7.2)$ & 128.9 & $6,6 a, 3 a$ & $9.12(d, 4.2)$ & 159.3 & $9 b, 6,6 a, 3 a, 5$ \\
\hline 6 & $6.90(d, 7.2)$ & 113.0 & $7,9 b, 5$ & $7.79(d, 4.2)$ & 124.7 & $7,9 b, 6,5$ \\
\hline $6 a$ & & 132.8 & & & 139.5 & \\
\hline 7 & 7.07 (s) & 100.9 & $6,9 b, 9,8$ & $7.11(s)$ & 110.9 & $7,9 b, 6,8,9$ \\
\hline 8 & & 157.5 & & & 157.9 & \\
\hline 9 & & 132.0 & & & 180.0 & \\
\hline $9 a$ & & 133.8 & & & 148.8 & \\
\hline $9 b$ & & 116.7 & & & 119.9 & \\
\hline $8-\mathrm{OCH}_{3}$ & $3.95(s)$ & 55.6 & 8 & $4.02(s)$ & 57.6 & 8 \\
\hline $9-\mathrm{OH}$ & $4.06(s)$ & 59.7 & 9 & & & \\
\hline 4- $\mathrm{NCH}_{3}$ & $2.68(s)$ & 39.0 & & & & \\
\hline
\end{tabular}

Keterangan (Note): $\mathrm{C}$ (karbon/carbon), $\mathrm{H}$ (proton), $\mathrm{N}$ (nitrogen), $\mathrm{OCH}_{3}$ (metoksi/metoxy), $\mathrm{OH}$ (hidroksi/hydroxy), $\mathrm{CH}_{3}$ (metil/metyl) 
Tabel 3. Data spektrum NMR 9-metoksiaaptamin (5)

Tabel 3. NMR spectrum data of 9-metoxyaaptamine (5)

\begin{tabular}{|c|c|c|c|}
\hline \multirow{2}{*}{$\begin{array}{c}\text { Posisi (Position) } \\
\text { C/H }\end{array}$} & \multicolumn{3}{|c|}{5} \\
\hline & $\begin{array}{c}\delta^{1} H(m, \text { in } 400 \mathrm{MHz}) \\
\text { in } \mathrm{CD}_{3} \mathrm{OD}\end{array}$ & $\delta^{13} \mathrm{C}$ & HMBC \\
\hline 2 & $7.78(d, 7.2)$ & 141.1 & 3, 9a,3a \\
\hline 3 & $6.36(d, 7.2)$ & 97.6 & $9 b, 2$ \\
\hline $3 a$ & & 150.2 & \\
\hline 5 & $7.25(d, 7.2)$ & 128.8 & $6,6 a, 3 a$ \\
\hline 6 & $6.87(d, 7.2)$ & 113.0 & $7,9 b, 5$ \\
\hline $6 a$ & & 132.8 & \\
\hline 7 & 7.04 (s) & 100.9 & $6,9 b, 9,8$ \\
\hline 8 & & 157.4 & \\
\hline 9 & & 131.9 & \\
\hline $9 a$ & & 133.7 & \\
\hline $9 b$ & & 116.6 & \\
\hline $8-\mathrm{OCH}_{3}$ & $4.05(\mathrm{~s})$ & 55.6 & 8 \\
\hline $9-\mathrm{OH}$ & $3.95(\mathrm{~s})^{*}$ & 59.7 & 9 \\
\hline
\end{tabular}

senyawa tersebut (Widanarni et al., 2004). Berdasarkan hasil uji pada (Tabel 5) didapatkan bahwa konsentrasi hambat minimum (KHM ) senyawa-2 adalah $100 \mathrm{mg} / \mathrm{L}$ atau setara dengan $2 \mu \mathrm{g} / \mathrm{disc}$. Daya hambat yang ditunjukkan oleh senyawa-2 pada konsentrasi 1.000 $\mathrm{mg} / \mathrm{L}(20 \mu \mathrm{g} / \mathrm{disc})$ lebih besar dibandingkan pada konsentrasi $750 \mathrm{mg} / \mathrm{L}(15 \mu \mathrm{g} / \mathrm{disc}), 500 \mathrm{mg} / \mathrm{L}(10 \mu \mathrm{g} /$ disc), dan $250 \mathrm{mg} / \mathrm{L}$ (5 $\mu \mathrm{g} /$ disc). Hal ini membuktikan bahwa pemberian konsentrasi senyawa yang semakin tinggi akan memberikan zona hambat yang semakin besar. Selain pengaruh konsentrasi, kemampuan suatu senyawa dalam menghambat pertumbuhan bakteri juga ditentukan oleh golongan senyawa tersebut (Ajizah,
2004). Dalam golongan senyawa aaptaminoid daya hambat diperngaruhi oleh hubungan aktivitas struktur turunan aaptaminoid ke aktivitas antibakterial dijumpai pada oksidasi gugus fungsi hidroksil $(\mathrm{OH})$ pada C-9 memberikan gugus fungsional karbonil $(C=0)$ yang menghasilkan peningkatan pada aktivitas antibakterial (Pettit et al., 2004).

\section{Potensi Senyawa Aaptaminoid Sebagai Antibakterial Terhadap Vibrio harveyi pada Udang (L. vannamei)}

Udang vaname yang diinjeksi dengan senyawa-2 tidak menunjukkan adanya kematian sampai hari ke-

Tabel 4. Aktivitas antibakterial senyawa (1-5) terhadap Vibrio harveyi Table 4. Antibacterial activity of compound (1-5) against Vibrio harveyi

\begin{tabular}{lc}
\hline \multicolumn{1}{c}{$\begin{array}{c}\text { Senyawa (kode) } \\
\text { Compounds (code) }\end{array}$} & $\begin{array}{c}\text { Zona hambatan } \\
\text { Inhibition zone (mm) }\end{array}$ \\
\cline { 2 - 2 } & Vibrio harveyi \\
\hline Aaptamin (1) & $12 \pm 0.3$ \\
9- demetilaaptamin (2) & $25 \pm 0.1$ \\
4-N -metilaaptamin (3) & $20 \pm 0.1$ \\
9-demetiloksiaaptamin (4) & $24 \pm 0.3$ \\
9-metoksiaaptamin (5) & $13 \pm 0.1$ \\
Streptomycine (kontrol positif/positive control) & $30 \pm 0.1$ \\
Metanol (kontrol negatif/negative control) & - \\
\hline
\end{tabular}

Keterangan (Note): (-) tidak ada hambatan (no inhibition) 
Tabel 5. Konsentrasi hambat minimum (KHM) senyawa-2 terhadap Vibrio harveyi

Table 5. M inimum inhibitory concentration (MIC) of compound-2 against Vibrio harveyi

\begin{tabular}{cc}
\hline $\begin{array}{c}\text { Konsentrasi } \\
\text { Concentration } \\
(\mathbf{m g} / \mathbf{L})\end{array}$ & $\begin{array}{c}\text { Zona hambatan } \\
\text { Inhibition zone }(\mathbf{m m})\end{array}$ \\
\cline { 2 - 2 } & Vibrio harveyi \\
\hline 1,000 & $25 \pm 0.3$ \\
500 & $21 \pm 0.1$ \\
250 & $16 \pm 0.1$ \\
100 & $15 \pm 0.3$ \\
10 & $14 \pm 0.1$ \\
1 & - \\
\hline
\end{tabular}

Keterangan (Note): (-) tidak ada hambatan (no inhibition)

14 pada semua perlakuan. Pada semua perlakuan senyawa aktif rata-rata udang telah moulting seperti ditunjukkan oleh kontrol. Selama 14 hari pemeliharaan sebelum uji tantang, udang terlihat bergerak aktif, pola renang aktif, permukaan badan, dan kulit bersih, dan sangat responsif terhadap stimulir. Selain itu, juga tidak didapatkan adanya sisa pakan baik pada kontrol maupun pada perlakuan. Ini menunjukkan bahwa senyawa-2 tidak menunjukkan efek toksik terhadap udang bahkan udang tumbuh dengan normal.

Sebaliknya setelah diuji tantang dengan V. harveyi, udang terlihat mengalami perubahan tingkah laku dan morfologi. Perubahan tingkah laku udang terlihat berenang dengan badan miring dan tidak lurus, kurang responsif terhadap stimulir, kehilangan nafsu makan yang diindikasikan oleh adanya sisa pakan dan usus yang kosong. Perubahan morfologi udang mulai terjadi pada 1,5 jam pasca uji tantang yaitu pereopoda dan antennal scale mulai memerah. Setelah 23 jam pascainfeksi pada perlakuan A dan B, seluruh permukaan badan, pleopoda, pereopoda, rostrum, dan telson udang memerah, sementara pada perlakuan $C$ dan $D$ perubahan warna tubuh tidak terlihat, perubahan terjadi pada rostrum, plopoda, pereopoda, dan telson namun tidak separah dengan perlakuan $\mathrm{A}$ dan $\mathrm{B}$. Berbeda dengan Manopo et al. (2011) dan Sari et al. (2015) yang menyatakan bahwa gejala klinis pada udang vaname yang diinfeksi V. harveyi muncul pada 48 jam. Ini menunjukkan bahwa V. harveyi yang digunakan sangat patogen terhadap udang vaname. Perubahan morfologi udang yang terinfeksi pada semua perlakuan selama penelitian ditunjukkan pada Gambar 2.

Pengamatan sintasan udang setelah 144 jam pasca penginfeksian menunjukkan bahwa rata-rata sintasan tertinggi pada perlakuan D sebesar 50\% Perlakuan C rata-rata sintasan sebesar $25 \%$ Sebaliknya perlakuan A dan $B$ semua udang sudah mengalami kematian sebelum 48 jam pasca penginfeksian. Rata-rata sintasan udang pasca penginfeksian ditunjukkan dalam Gambar 3.

Sintasan udang berkaitan dengan aktivitas senyawa2 sebagai antibakterial yang sangat kuat. Hal ini terlihat pada perubahan warna yang terjadi pada udang. Menurut Ulna et al. (2016), perubahan warna merupakan adanya penurunan imunitas tubuh udang, serta hal ini menunjukkan mulai bekerjanya imunitas tubuh untuk melawan benda asing dal am tubuh udang.

Pada penelitian ini perubahan warna udang (badan, telson, pereopoda, plopoda, dan rostrum memerah) pada pelakuan A dan B yang terjadi pada 1,5 jam pasca penginfeksian tidak berkurang dan ketahanan tubuh udang semakin lemah sehingga menyebabkan kematian dan setelah 23 jam pasca penginfeksian, semua udang tidak ada yang bertahan hidup. Kematian udang disebabkan oleh patogen yang dibuktikan oleh keberadaan bakteri V. harveyi yang diisolasi dari udang yang maribut sebelum akhirnya mati. Senyawa-2 pada konsentrasi $0,67 \mu \mathrm{g} / \mathrm{g}$ bb belum mampu meningkatkan pertahanan udang terhadap patogen. Berbeda dengan perlakuan $C$ dan $D$, udang yang sebelumnya terinfeksi berangsur-angsur pulih yang ditandai dengan perubahan warna rostrum, pereopoda, dan telson (Gambar 4) yang terjadi mulai pada hari keempat. Sejak hari keempat pasca penginfeksian, udang mulai terlihat ada nafsu makan yang ditandai dengan usus mulai berisi pakan, sudah responsif terhadap stimulir dan mulai aktif bergerak sehingga sejak hari ke-4 sampai hari ke-7 pasca penginfeksian sudah tidak didapatkan udang yang mati. Ini menunjukkan bahwa senyawa-2 pada dosis tersebut berhasil menghambat perkembangan 


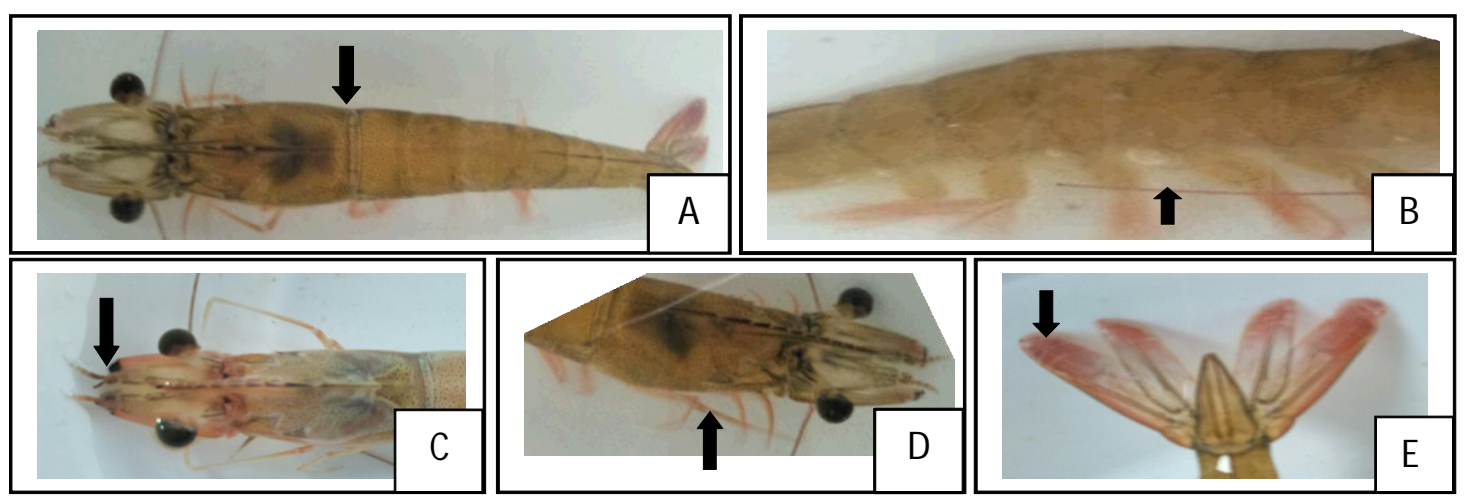

Keterangan: Badan memerah (A), pleopoda memerah (B), rostrum memerah (C), pereopoda memerah (D), dan telson memerah (E)

Note: $\quad$ Reddish on body (A), pleopoda (b), rostrum (c), pereopoda (d), and telson (E)

Gambar 2. Perubahan morfologi udang (L. vannamei) 23 jam pasca penginfeksian V. harveyi.

Figure 2. Morphology change of $\mathbf{L}$. vannamei at 23 hourspost $\mathbf{V}$. harveyi infection.

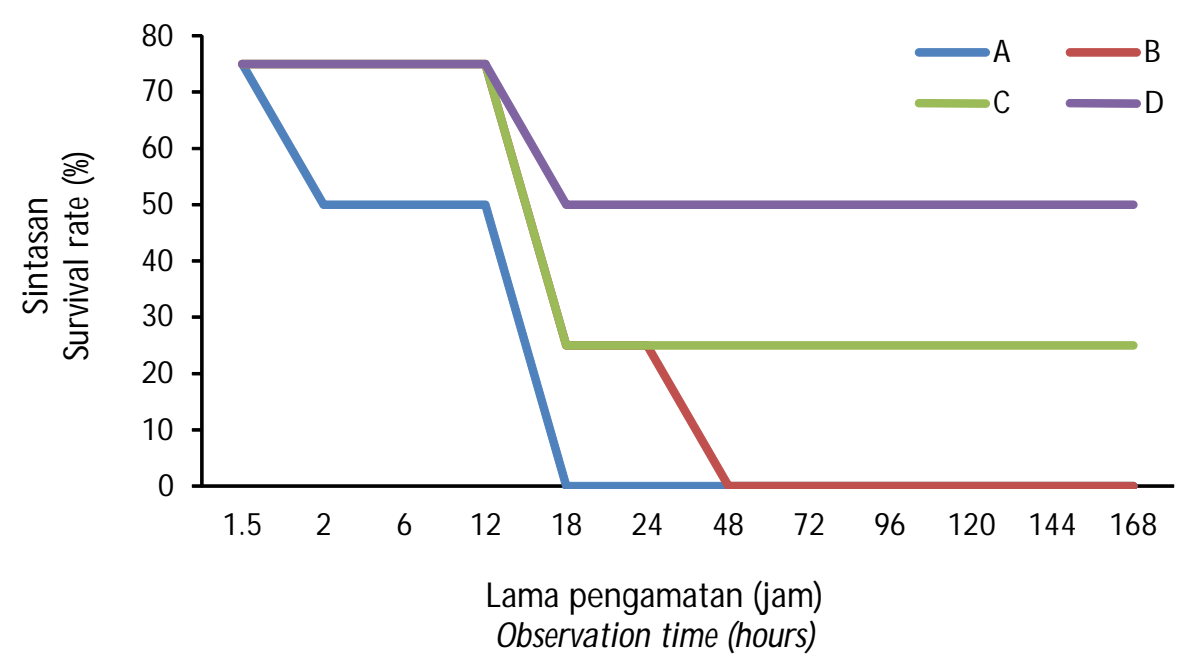

Keterangan: A) $0 \mu \mathrm{g} / \mathrm{g}$ bb; B) $0,67 \mu \mathrm{g} / \mathrm{g}$ bb; C) $25 \mu \mathrm{g} / \mathrm{g}$ bb; dan D) $50 \mu \mathrm{g} / \mathrm{g}$ bb Note: $\quad$ A) $0 \mu \mathrm{g} / \mathrm{g} b \mathrm{~b}$; B) $0.67 \mu \mathrm{g} / \mathrm{g} b \mathrm{~b}$; C) $25 \mu \mathrm{g} / \mathrm{g} b \mathrm{~b}$; and D) $50 \mu \mathrm{g} / \mathrm{g} \mathrm{bb}$

Gambar 3. Sintasan udang vaname (L. vannamei) pada jam ke-1,5; $2,6,12$, $18,24,48,72,96,120$, dan 144 jam pasca penginfeksian V. harveyi.

Figure 3. Survival rate of $L$. vannamei at $1,5,2,6,12,18,24,48,72,96$, 120 , and 144 hours after $\mathbf{V}$. harveyi infection.

V. harveyi sehingga perkembangan dan patogenitas dalam tubuh udang menurun. Menurut Saptiani et al. (2013), perlakuan vaksin ataupun adanya uji tantang dapat menstimulir peningkatan pembentukan sel-sel imunitas. Adanya bahan asing atau infeksi yang masuk ke dalam tubuh akan menimbulkan respons kekebalan atau peradangan yang nantinya akan diikuti pembentukan zat kebal yang dihasilkan oleh sel-sel radang, yang selanjutnya meransang proliferasi dan deferensiasi sel imunitas yang satu di antaranya berfungsi membentuk bahan spesifik yang disebut antibodi.

\section{KESIMPULAN}

Dari ekstrak butanol aktif Aaptos aaptos telah diisolasi lima senyawa turunan aaptaminoid yang diidentifikasi sebagai aaptamin (1), 9-demetilaaptamin (2), 4-N-metilaaptamin (3), 9-demetiloksiaaptami (4), dan 9-metoksiaaptamin (5). Kelima senyawa tersebut mampu menghambat pertumbuhan $\mathrm{V}$. harveyi in vitro. Uji lanjut terhadap V. harveyi pada udang menunjukkan bahwa 9-demetilaaptamin dapat dikembangkan sebagai antibakterial alami pada udang vaname (L. vannamei) dalam menanggulangi vibriosis. 

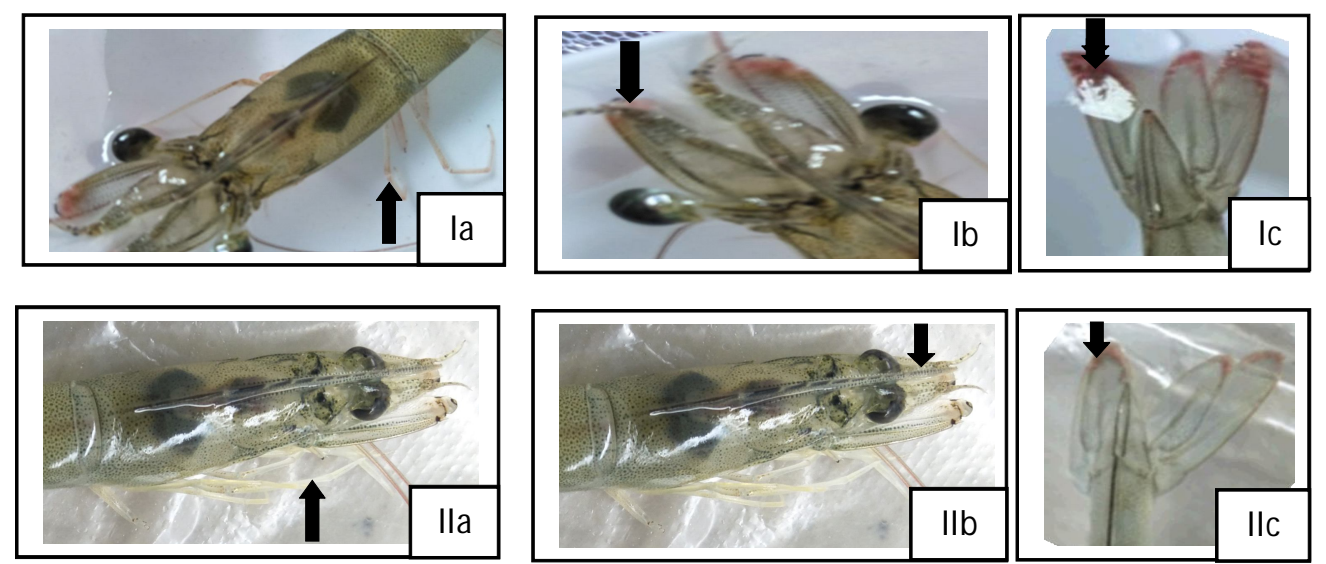

Gambar 4. Perubahan morfologi udang yang bertahan hidup sampai 144 jam pasca penginfeksian V. harveyi pada perlakuan C dan D. Keterangan: Pereopoda (Ia), rostrum (Ib) dan telson (IC) yang memerah 23 jam pasca penginfeksian, pereopoda (IIa), rostrum (IIb) dan telson (IIC) yang kembali normal pada 144 jam pasca penginfeksian.

Figure 4. Morphological changes of survived shrimp during 144 hours post V. harveyi infection in treatment $C$ and $D$. Note: Reddish of pereopoda (la), rostrum (Ib) and telson (IC) at 23 hourspost infection, pereopoda (Ila), rostrum (IIb) and telson (IIC) back to normal at 144 hours post infection.

\section{UCAPAN TERIMA KASIH}

Penelitian ini merupakan lanjutan dari penelitian yang dibiayai oleh Pemerintah Provinsi Sulawesi Selatan dan Kemenristekdikti melalui program INSINAS Tahun 2015; untuk itu, diucapkan terima kasih atas pembiayaannya. Ucapan terima kasih juga penulis sampaikan kepada Ridwan, S.Pi. (staf Marine Station Unhas) untuk koleksi sampel sponge dan Dr. Ince Ayu Khairana Kodriah, S.Pi., M.Sc. atas koleksi Vibrio harveyi.

\section{DAFTAR ACUAN}

Ajizah, A. (2004). Sensitivitas Salmonella typhimurium terhadap ekstrak daun Psidium guajava L. Bioscientiae, 1(1), 8-31.

Ambari, M. (2018). Upaya mencari obat penyakit udang dari tanaman bakau, seperti apa?. https:// www.mongabay.co.id/2018/08/10/upaya-mencariobat-penyakit-udang-dari-tanaman-bakau-sepertiapa/. Diakses Tanggal 4 Juli 2019.

Calcul, L., Longeon, A., Mourabit, A.A., Guyot, M., \& Bourguet-Kondracki, M.L. (2003). Novel alkaloids of the aaptamine class from an Indonesian marine sponge of the genus Xetospongia. Tetrahedron, 59, 6539-6544.

Davis, W.W. \& Stout,. T.R. (1971). Disc plate method of microbiological antibiotic assay. Appl. Microbiol., $22(4), 659-665$.
Herlt, A., Mander, L., Rombang, W., Rumampuk, R., Soemitro, S., Steglich, W., Tarigan, P., \& Nussbaum, F.V. (2004). Alkaloids from marine organisms. Part 8: Isolation of bisdemethylaaptamine and bisdemethylaaptamine-9-0-sulfate from an Indonesian Aaptos sp. marine sponge. Tetrahedron, 60, 6101-6104.

Manopo, H. (2011). Peran nukleotidase sebagai immunostimulan terhadap respons imun nonspesifik dan resistensi udang vaname (L. vannamei). Skripsi. Institut Pertanian Bogor.

Mohamad, H., Rosmiati, Muhammad, T.S.T., Andriani, Y., Bakar, K., Ismail, N., Saidin, J., Latip, J., Musa, N., \& Parenrengi, A. (2017). Potential secondary metabolites from marine sponge Aaptos aaptos for atherosclerosis and vibriosis treatments. Natural Product Communications, 12(8), 1227-1230.

Mayer, A.M. \& Hamman, M.T. (2002). Review marine pharmacology in 1999: Compounds with antibacterial, anticoagulant, antifungal, anthelmintic, anticardiovascular, endocrine, immune and nervous systems and other miscellaneous mechanisms of action. Comparative Biochemistry and Physiology Part C, 132, 315-339.

Pedpradab, S. (2005). Isolation and structure elucidation of secondary metabolites from marine sponges and a marine-derived fungus. Ph.D. Thesis. Universität Düsseldorf, Germany. 
Pettit, G.R., Hoffmann, H., Herald, D.L., Blumberg, P.M., Hamel, E., Schmidt, J.M., Chang, Y., ..... \& Pearce, L.V. (2004). Antineoplastic agents. 499. Synthesis of hystatin 2 and related $1 \mathrm{H}$ benzo[de][1,6]-naphthyridinium salts from aaptamine. J. Med. Chem., 47, 1775-1782.

Radji, M. (2011). Mikrbiologi. Jakarta: ECG Press, $50 \mathrm{hlm}$.

Rosmiati, Mohamad, H., Muhammad, T.S.T., Musa, N., Ahmad, A., Ismail, N., \& Mohamad, F. (2011). In vitro antagonist activities of Indonesian marine sponges Aaptos aaptos and Callyspongia pseudoreticulata extracts and their toxicity against Vibrio spp. Indonesian Aquaculture Journal, 6(1), 173182.

Rosmiati \& Muliani. (2019). Study on the potential of Aaptos aaptos aqueous extract as an antibacterial agent against Vibrio harveyi in tiger shrimp (Penaeus monodon Fabricius) post larvae. IOP Conf. Ser.: Earth Environ. Sci., 253, 1-7.

Saptiani, G., Prayitno, S.B., \& Anggoro, S. (2013). Potensi antibakteri ekstrak daun jeruju (Acanthus ilcifolius) terhadap Vibrio harveyi secara in-vitro. Jurnal Kedokteran Hewan, 7(1), 17-20.
Sari, R.R.B., Sarjito, \& Haditomo, A.H.C. (2015). Pengaruh penambahan serbuk daun binahong (Anredera cordifolia) dalam pakan terhadap kelulushidupan dan histopatologi hepatopankreas udang vaname (L. vannamei) yang diinfeksi bakteri (Vibrio harveyi). J. of Aquaculture Management and Technology, 4(1), 26-32.

Septiana, E. \& Simanjuntak, P. (2015). Aktifitas antimikroba dan antioksidan ekstrak beberapa bagian tanaman kunyit (Curcuma longa). Fitofarmaka, 5(1), 2087-9164.

Sukenda. (2007). Penggunaan kitosan untuk pengendalian infeksi Vibrio harveyi pada udang putih (L. vannamei). Jurnal Akuakultur Indonesia, 6(2), 205-209.

Ulna, Saptiani, G., \& Hardi, E.H. (2016). Aktivitas antibakterial ekstrak daun Sonneratia alba terhadap Vibrio harveyi pada benur udang windu (Penaeus monodon). J. Aquawarman, 2(2), 35-44.

Widanarni, Meha, D., Nuryati, S., Sukenda, \& Suwanto, A. (2004). Uji patogenisitas Vibrio harveyi pada larva udang windu menggunakan resisten rifampisin sebagai penanda molekuler. Jurnal Akuakultur Indonesia, 3(3), 23-27. 